\title{
Effects of Prunus mume Siebold \& Zucc. in the pacemaking activity of interstitial cells of Cajal in murine small intestine
}

\author{
SANG WEON LEE ${ }^{1,2}$, SUNG JIN KIM ${ }^{1,2}$, HYUNGWOO KIM ${ }^{3}$, \\ DONGKI YANG ${ }^{4}$, HYUN JUNG KIM ${ }^{5}$ and BYUNG JOO KIM ${ }^{5}$
}

\begin{abstract}
${ }^{1}$ Department of Neurosurgery; ${ }^{2}$ Research Institute for Convergence of Biomedical Science and Technology, Pusan National University Yangsan Hospital, Yangsan, Gyeongsangnam 50612; ${ }^{3}$ Division of Pharmacology, Pusan National University School of Korean Medicine, Yangsan, Gyeongsangnam 50612; ${ }^{4}$ Department of Physiology, Gachon University College of Medicine, Incheon, Gyeonggi 22332; ${ }^{5}$ Division of Longevity and Biofunctional Medicine, Pusan National University School of Korean Medicine, Yangsan, Gyeongsangnam 50612, Republic of Korea
\end{abstract}

Received July 15, 2015; Accepted September 20, 2016

DOI: $10.3892 /$ etm.2016.3963

\begin{abstract}
Interstitial cells of Cajal (ICCs) function as pacemaker cells in the gastrointestinal (GI) tract and therefore, serve an important role in regulating GI motility. The effects of a species of plum (Prunus mume Siebold \& Zucc.) on cultured ICC cluster-induced pacemaker potentials in the mouse small intestine were investigated, and the effects of a methanolic extract of Prunus mume (m-PM) on ICC pacemaker activities were examined using the whole-cell patch-clamp technique. ICC pacemaker membrane potentials were depolarized by $\mathrm{m}-\mathrm{PM}$ in a concentration dependent manner in current clamp mode. 4-Diphenylacetoxy-N-methyl-piperidine methiodide, which is a muscarinic $3\left(\mathrm{M}_{3}\right)$ receptor antagonist, was able to block m-PM-induced pacemaker potential increases, whereas methoctramine, which is a muscarinic 2 $\left(\mathrm{M}_{2}\right)$ receptor antagonist, was not. When $1 \mathrm{mM}$ guanosine diphosphate $\beta-5$ was present in the pipette solution, m-PM induced slight pacemaker depolarization. Following pretreatment in bath solution of $\mathrm{Ca}^{2+}$-free solution or a $\mathrm{Ca}^{2+}$-ATPase inhibitor in endoplasmic reticulum, the pacemaker currents were inhibited. Furthermore, pretreatment with PD98059, SB203580 or SP600125, which is a c-jun NH2-terminal kinase inhibitor, blocked m-PM-induced ICC potential depolarization. Furthermore, m-PM inhibited transient receptor potential melastatin (TRPM) 7 channels, but did not affect $\mathrm{Ca}^{2+}$-activated $\mathrm{Cl}^{-}$channels. These results suggest that m-PM is able to modulate pacemaker potentials through the muscarinic $\mathrm{M}_{3}$ receptor, via G-protein and external and internal $\mathrm{Ca}^{2+}$,
\end{abstract}

Correspondence to: Professor Byung Joo Kim, Division of Longevity and Biofunctional Medicine, Pusan National University School of Korean Medicine, Beomeori, Mulgeum-eup, Yangsan, Gyeongsangnam 50612, Republic of Korea

E-mail: vision@pusan.ac.kr

Key words: interstitial cells of Cajal, plum, Prunus mume Siebold \& Zucc., gastrointestinal tract in a mitogen-activated protein kinase and TRPM7-dependent manner. Therefore, $\mathrm{m}-\mathrm{PM}$ may provide a basis for the development of a novel gastroprokinetic agent.

\section{Introduction}

The fruit of the plum tree Prunus mume Siebold \& Zucc. (PM) is used across East Asia, particularly in Korea and Japan (1), as a traditional herbal medicine for the relief of digestive problems, fatigue and fever. PM contains a number of phenolic compounds, including phenolic acids and flavonoids $(1,2)$, which have antioxidant and free radical scavenging activities in vivo (3-6). Furthermore, PM extracts exhibit many pharmacological activities, including antimicrobial (7-10), immune enhancing (11), anti-cancer $(1,12,13)$, and anti-fatigue (14) effects, and have been demonstrated to enhance osteoclast differentiation (15) and improve blood flow (16). Additionally, previous studies have reported that using PM extracts with probiotics inhibits the development of atopic dermatitis (17) and enhances immunity (18).

Interstitial cells of Cajal (ICCs) are the pacemakers of the gastro-intestinal tract and generate rhythmic responses in cell membrane electrical potentials $(19,20)$, thus serving important roles in the regulation of GI motility (21). Additionally, endogenous agents are able to regulate GI motility function via ICCs (22-25). Furthermore, transient receptor potential melastatin (TRPM) 7 (26) or $\mathrm{Cl}^{-}$channels, such as anoctamin1 (ANO1) (27-29), are associated with pacemaker potentials in the GI tract. Therefore, TRPM7 and ANO1 may be therapeutic targets for the treatment of GI motility disorders.

It has been reported previously that PM is able to enhance the propulsive motion and motility of the small intestine (7) and promote the frequency of defecation and colon contraction in rats, which supports the potential role of PM as a therapeutic agent for the treatment of constipation (30). However, little is known about the effect of PM on ICC clusters in the GI tract. The aims of the present study were to evaluate the effects of the methanoic extract of PM (m-PM) on the electrical pacemaker potentials of cultured ICCs and characterize m-PM-mediated signaling pathways. 


\section{Materials and methods}

Preparation of $m-P M$. PM fruits were harvested in the Wondong area, (Yangsan, Geongnam, Korea) in June 2012 and were authenticated by Professor Hyungwoo Kim (School of Korean Medicine, Pusan National University, Yangsan, Korea). A standard extraction process was performed to obtain m-PM, as previously described (24). Briefly, $50 \mathrm{~g} \mathrm{PM}$ fruit was immersed in 0.51 methanol, sonicated for $15 \mathrm{~min}$ and allowed to stand for $24 \mathrm{~h}$. The extract obtained was filtered through No. 20 Whatman filter paper and lyophilized using a freeze dryer (Labconco Corp., Kansas City, MO, USA). A total of $2.42 \mathrm{~g}$ of lyophilized powder (m-PM) was subsequently obtained (yield, 4.84\%). A $12.1 \mathrm{~g}$ sample of $\mathrm{m}-\mathrm{PM}$ was deposited at the School of Korean Medicine, Pusan National University (voucher no. MH2012-008).

Ethics. Animal care and experiments were conducted in accordance with the guidelines issued by the ethics committee of Pusan National University (Busan, Korea; Approval no. PNU-2014-0725) and the National Institutes of Health Guide for the Care and Use of Laboratory Animals (31).

Preparation of cells and cell cultures. A total of 78 BALB/c mice (male:female, 41:37; age, 4-7 days; weight, 2.0-2.2 g; Samtako Bio Korea Co., Ltd., Osan, Korea) were anesthetized with $0.1 \%$ ether (Sigma-Aldrich; Merck Millipore, Darmstadt, Germany) and sacrificed using cervical dislocation. Mice were maintained under controlled conditions (temperature, $20 \pm 2{ }^{\circ} \mathrm{C}$; humidity, $50 \pm 5 \%$; $12 \mathrm{~h}$ light/dark cycles) and were allowed free access to food and water. Small intestines were removed and opened along the mesenteric border, and luminal contents were removed via washing with Krebs-Ringer bicarbonate solution. Sharp dissection was performed to remove small intestine mucosae and small strips of intestine muscle were subsequently equilibrated in $\mathrm{Ca}^{2+}$-free physiological salt solution (in mmol/l: $125 \mathrm{NaCl}, 5.36 \mathrm{KCl}, 0.34 \mathrm{NaOH}$, $0.44 \mathrm{Na}_{2} \mathrm{HCO}_{3}, 10$ glucose, 2.9 sucrose, and 11 HEPES buffer) for $20 \mathrm{~min}$ and dispersed using an enzyme solution containing $1.5 \mathrm{mg} / \mathrm{ml}$ collagenase (Worthington Biochemical Corp., Lakewood, NJ, USA), $2.5 \mathrm{mg} / \mathrm{ml}$ bovine serum albumin (Sigma-Aldrich; Merck Millipore), $2.5 \mathrm{mg} / \mathrm{ml}$ trypsin inhibitor (Sigma-Aldrich; Merck Millipore) and $0.5 \mathrm{mg} / \mathrm{ml}$ adenosine triphosphate (ATP) (Sigma-Aldrich; Merck Millipore). Cells were plated on glass coverslips coated with $0.01 \%$ poly-L-lysine solution (Sigma-Aldrich; Merck Millipore) and cultured in an atmosphere containing 95\% $\mathrm{O}_{2}$ and $5 \% \mathrm{CO}_{2}$ in smooth muscle basal medium (Clonetics Corp.; Lonza, Walkersville, MA, USA) supplemented with stem cell factor ( $5 \mathrm{ng} / \mathrm{ml}$; Sigma-Aldrich; Merck Millipore) and $1 \%$ penicillin/streptomycin (Gibco; Thermo Fisher Scientific, Inc., Waltham, MA, USA) at $37^{\circ} \mathrm{C}$.

Whole cell patch-clamp experiments. The $\mathrm{Na}^{+}$-Tyrode solution used in bath solution contained $135 \mathrm{mM} \mathrm{NaCl}, 5 \mathrm{mM}$ $\mathrm{KCl}, 135 \mathrm{mM} \mathrm{NaCl}, 2 \mathrm{mM} \mathrm{CaCl}{ }_{2}, 10 \mathrm{mM}$ glucose, $1.2 \mathrm{mM}$ $\mathrm{MgCl}_{2}$ and $10 \mathrm{mM}$ 4-(2-hydroxyethyl)-1-piperazineethanesulfonic acid (HEPES) buffer, adjusted to $\mathrm{pH} 7.4$ with $\mathrm{NaOH}$. A pipette solution was also used, which contained $140 \mathrm{mM} \mathrm{KCl}, 5 \mathrm{mM} \mathrm{MgCl}$, $2.7 \mathrm{mM} \mathrm{K}_{2} \mathrm{ATP}, 0.1 \mathrm{mM} \mathrm{Na}$ guanosine triphosphate (GTP), $2.5 \mathrm{mM}$ creatine phosphate disodium, $5 \mathrm{mM}$ HEPES buffer and $0.1 \mathrm{mM}$ ethylene glycol bis (2-aminoethyl ether)- $N, N, N^{\prime}, N^{\prime}$-tetraacetic acid (EGTA), adjusted to $\mathrm{pH} 7.2$ with $\mathrm{KOH}$. The whole-cell patch-clamp technique was performed to record the membrane electrical potentials in cultured ICCs and membrane potentials were amplified using an Axopatch 1-D (Molecular Devices, LLC, Sunnyvale, CA, USA). Command pulses were applied using a Samsung-compatible personal computer and pClamp software (ver. 9.0; Molecular Devices). Data were filtered at $1 \mathrm{kHz}$ and displayed on a computer monitor. pClamp and Origin software (ver. 8.0; MicroCal, Northampton, MA, USA) were used for statistical analysis. All experiments were performed at $30^{\circ} \mathrm{C}$.

TRPM7 overexpression. Human embryonic kidney (HEK)-293 cells (American Type Culture Collection, Manassas, VA, USA) were transfected with Flag-murine LTRPC7/pCDNA4-TO construct and subsequently cultured in Dulbecco's Modified Eagle medium (Thermo Fisher Scientific, Inc.) supplemented with $5 \mu \mathrm{g} / \mathrm{ml}$ blasticidin, $0.4 \mathrm{mg} / \mathrm{ml}$ zeocin and $10 \%$ fetal bovine serum (Thermo Fisher Scientific, Inc.). Adding $1 \mu \mathrm{g} / \mathrm{ml}$ tetracycline to the medium for $24 \mathrm{~h}$ induced TRPM7 overexpression. HEK293 cells overexpressing TRPM7 were bathed in a solution containing $145 \mathrm{mM} \mathrm{NaCl}, 2.8 \mathrm{mM}$ $\mathrm{KCl}, 2 \mathrm{mM} \mathrm{CaCl}_{2}, 10 \mathrm{mM}$ glucose, $1.2 \mathrm{mM} \mathrm{MgCl}_{2}$ and $10 \mathrm{mM}$ HEPES buffer, adjusted to $\mathrm{pH} 7.4$ with $\mathrm{NaOH}$. The pipette solution contained $145 \mathrm{mM}$ Cs-glutamate, $8 \mathrm{mM} \mathrm{NaCl}, 10 \mathrm{mM}$ Cs-2-bis (2-aminophenoxy)-ethane- $N, N, N^{\prime}, N^{\prime}$-tetraacetic acid, and $10 \mathrm{mM}$ HEPES-CsOH, adjusted to $\mathrm{pH} 7.3$ with $\mathrm{CsOH}$.

$\mathrm{Ca}^{2+}$ activated $\mathrm{Cl}^{-}$channel overexpression. HEK-293 cells were transfected with the pEGFP-N1-mANO1 construct for $24 \mathrm{~h}$ and these cells were cultured on glass coverslips in Dulbecco's Modified Eagle medium, which was supplemented with $10 \%$ fetal bovine serum. The bath solution contained $146 \mathrm{mM} \mathrm{HCl}$, $10 \mathrm{mM}$ HEPES, $10 \mathrm{mM}$ glucose, $1 \mathrm{mM} \mathrm{MgCl}$, $1 \mathrm{mM} \mathrm{CaCl}$ and $150 \mathrm{mM}$ N-methyl-D-glucamine (NMDG), adjusted to $\mathrm{pH}$ 7.4. The pipette solution contained $150 \mathrm{mM}$ NMDG-Cl, $1 \mathrm{mM} \mathrm{MgCl}$, 3 mM MgATP, $10 \mathrm{mM}$ EGTA, $5 \mathrm{mM} \mathrm{CaCl} \mathrm{m}_{2}$ and $5 \mathrm{mM}$ HEPES buffer at pH 7.2 (titrated with NMDG). WEBMAX-C STANDARD software (C. Patton, Stanford University, www.stanford.edu/ cpatton/maxc.html) was used to fix the free calcium concentration at $200 \mathrm{nM}$.

Pharmacological agents. Pharmacological agents, including methoctramine, 4-diphenylacetoxy-N-methyl-piperidine methiodide (4-DAMP), guanosine 5'-O-(2-thiodiphosphate) (GDP- $\beta$-S), thapsigargin, PD98059, SB203580 and SP600125, were purchased from Sigma-Aldrich (Merck Millipore). They were dissolved in dimethyl sulfoxide (DMSO) or distilled water and stored at $-20^{\circ} \mathrm{C}$. The final concentration of DMSO in the bath solution was maintained at $<0.1 \%$.

Statistical analysis. Results are expressed as mean \pm standard error of the means. Student's $t$-test for unpaired data was performed to compare control and experimental groups. Origin software (version 8.0; OriginLab, Northampton, MA, USA) was used to perform statistical analysis. $\mathrm{P}<0.05$ was considered to indicate a statistically significant difference. 

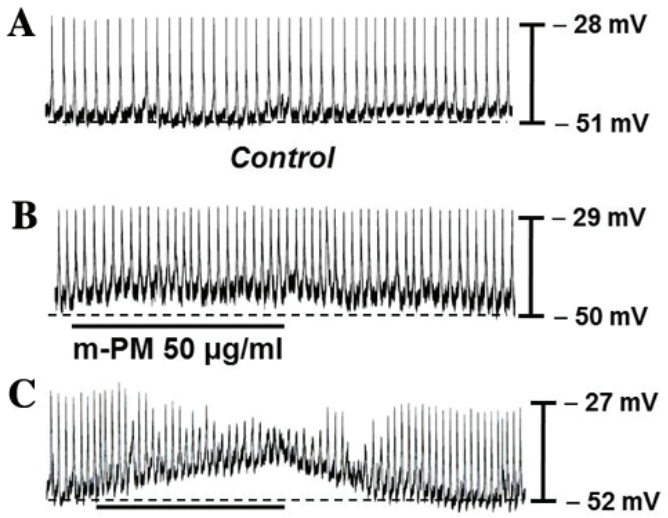
$\mathrm{m}-\mathrm{PM} 100 \mu \mathrm{g} / \mathrm{ml}$
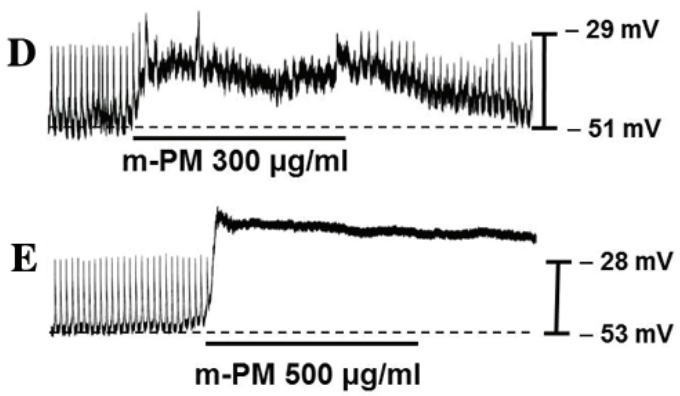
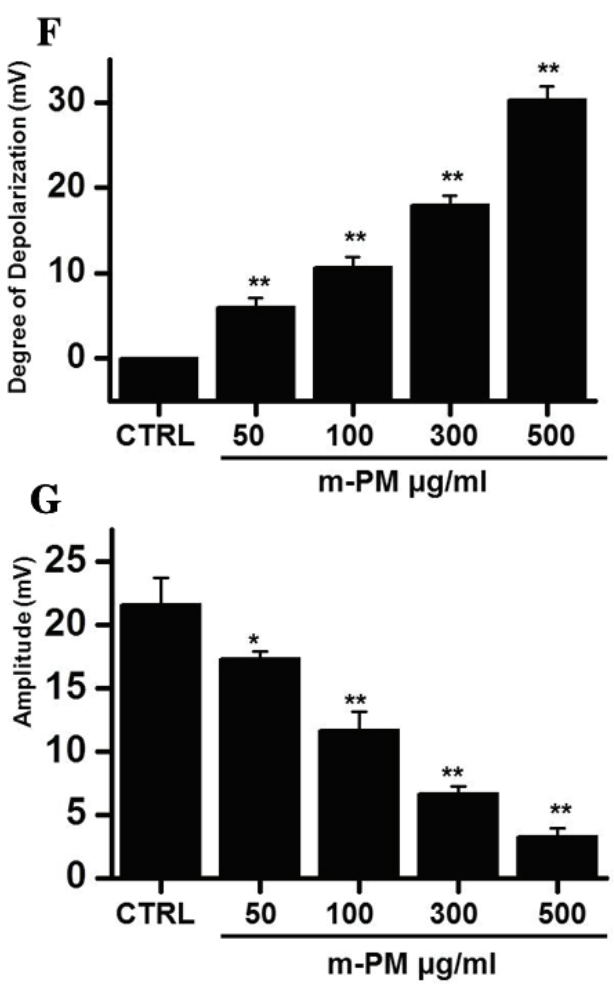

Figure 1. Effects of m-PM on the pacemaker potentials of cultured ICCs from murine small intestine. (A-E) Pacemaker potentials of ICCs exposed to $\mathrm{m}-\mathrm{PM}(50-500 \mu \mathrm{g} / \mathrm{ml})$ in current clamping mode $(\mathrm{I}=0)$. Responses to $\mathrm{m}-\mathrm{PM}$ are summarized in $(\mathrm{F}$ and $\mathrm{G})$. Bars represent mean values \pm standard deviation. ${ }^{*} \mathrm{P}<0.05$ vs. control, ${ }^{* *} \mathrm{P}<0.01$ vs. control. m-PM, methanoic extract of the fruits of Prunus mume Siebold \& Zucc.; ICCs, interstitial cells of Cajal; CTRL, control.

\section{Results}

Effect of m-PM on pacemaker electrical potentials in cultured ICCs. The effect of m-PM on pacemaker electrical potentials in cultured ICCs was investigated. Mean resting electrical potential of membranes was $-51.7 \pm 2.4 \mathrm{mV}$ and the electrical amplitude was $21.6 \pm 2.3 \mathrm{mV}$. Following m-PM administration $(50-500 \mu \mathrm{g} / \mathrm{ml})$, mean membrane electrical potentials were depolarized to $6.2 \pm 1.3(50 \mu \mathrm{g} / \mathrm{ml}), 10.6 \pm 1.2(100 \mu \mathrm{g} / \mathrm{ml})$, $18.5 \pm 1.5(300 \mu \mathrm{g} / \mathrm{ml})$ and $30.3 \pm 1.6 \mathrm{mV}(500 \mu \mathrm{g} / \mathrm{ml}$; Fig. 1A-E), and corresponding amplitudes decreased to $17.3 \pm 0.6$, $11.4 \pm 1.5,6.7 \pm 0.8$, and $3.3 \pm 0.5 \mathrm{mV}$, respectively (Fig. 1B-E). The effects of $\mathrm{m}-\mathrm{PM}$ on pacemaker electrical potentials are presented in Fig. $1 \mathrm{~F}$ and $\mathrm{G}(\mathrm{n}=7)$. These results suggest that m-PM modulates the pacemaker potentials of ICCs.

$m-P M$ receptors in cultured ICCs. To study the m-PM receptors on ICCs, muscarinic receptors were investigated as they mediate membrane electrical depolarization in the GI tract $(32,33)$. Furthermore, it has been demonstrated that ICCs express $M_{2}$ and $M_{3}$ muscarinic receptors in the GI tract (34). Pretreatment with muscarinic receptor antagonists was performed to identify which muscarinic receptor was associated with the response. Membranes were pretreated with $10 \mu \mathrm{m}$ methoctramine, which is a muscarinic $\mathbf{M}_{2}$ receptor antagonist, or 4-DAMP, which is a muscarinic $\mathrm{M}_{3}$ receptor antagonist, for $5 \mathrm{~min}$ prior to $\mathrm{m}-\mathrm{PM}(300 \mu \mathrm{g} / \mathrm{ml})$ administration. Neither antagonist had any effect on pacemaker potentials. Methoctramine did not inhibit the effect of m-PM (Fig. 2A), whereas 4-DAMP was able to inhibit
m-PM-induced membrane depolarization (Fig. 2B). The mean membrane electrical depolarization by m-PM following pretreatment with methoctramine or 4 -DAMP was $17.5 \pm 0.7$ and $0.9 \pm 0.4 \mathrm{mV}$, respectively $(\mathrm{n}=5$ in each; Fig. $2 \mathrm{C}$ ). These results indicate that $\mathrm{m}-\mathrm{PM}$ affects ICCs through $\mathrm{M}_{3}$ receptors, not $\mathrm{M}_{2}$ receptors.

Association between $G$ proteins and m-PM-induced pacemaker electrical potentials in cultured ICCs. GDP- $\beta-S$, which permanently inactivates G-protein binding proteins $(35,36)$, was administered to determine whether G-proteins are associated with the effects of m-PM on cultured ICCs. m-PM $(300 \mu \mathrm{g} / \mathrm{ml})$ induced ICC membrane depolarization (Fig. 1D); however, when GDP- $\beta$-S $(1 \mathrm{mM})$ was present in the pipette solution, m-PM-induced depolarization was markedly reduced ( $\mathrm{n}=5$; Fig. 3). These results suggest that $\mathrm{G}$-proteins have a role in the $\mathrm{m}-\mathrm{PM}$-induced pacemaker depolarization of ICCs.

Effects of external $\mathrm{Ca}^{2+}$-free solution and $\mathrm{Ca}^{2+}$-ATPase inhibitor of endoplasmic reticulum on $m$-PM-induced pacemaker electrical potentials of cultured ICC. An influx of external $\mathrm{Ca}^{2+}$ is required for GI contractions and pacemaker electrical depolarizations in ICCs (37). Furthermore, pacemaker electrical depolarizations are regulated by intracellular $\mathrm{Ca}^{2+}$ modulations (37). To investigate the roles of external and internal $\mathrm{Ca}^{2+}$ on m-PM-induced pacemaker depolarizations, $\mathrm{m}-\mathrm{PM}$ was applied in the absence of external $\mathrm{Ca}^{2+}$ and in the presence of thapsigargin $\left(\mathrm{a} \mathrm{Ca}^{2+}\right.$-ATPase inhibitor in endoplasmic reticulum). When exposed to the external 
A

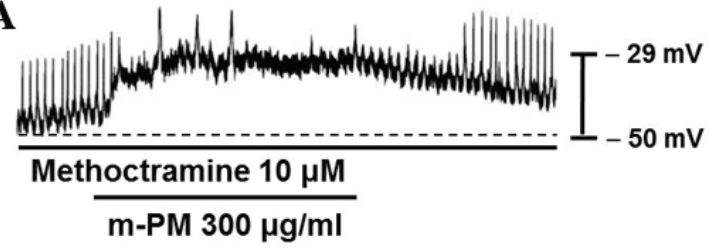

B

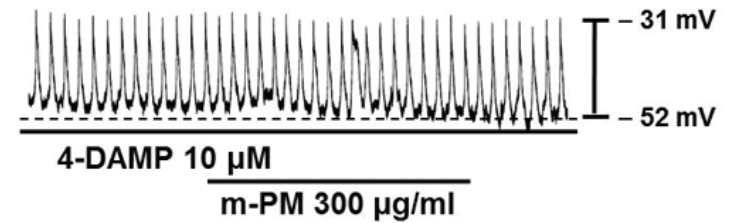

C

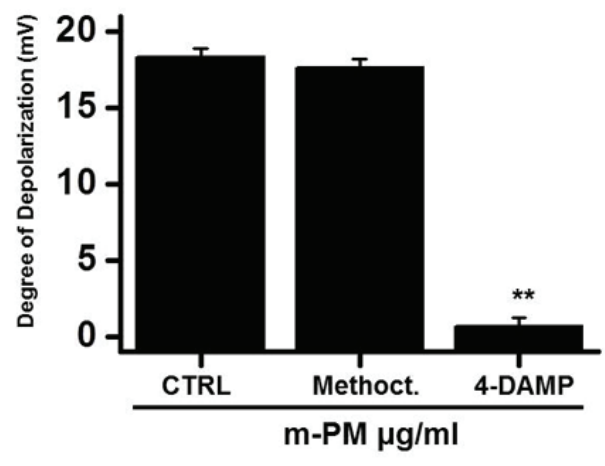

Figure 2. Effects of muscarinic receptor subtype antagonists on m-PM-induced pacemaker potential depolarizations in cultured ICCs. (A) Pacemaker potentials of ICCs were depolarized following exposure to $\mathrm{m}-\mathrm{PM}(300 \mu \mathrm{g} / \mathrm{ml})$ in the presence of methoctramine (a muscarinic $\mathrm{M}_{2}$ receptor antagonist; $\left.10 \mu \mathrm{M}\right)$. (B) Pacemaker potentials of ICCs were not affected by exposure to $\mathrm{m}-\mathrm{PM}$ in the presence of 4-DAMP (a muscarinic $\mathrm{M}_{3}$ receptor antagonist; $10 \mu \mathrm{M}$ ). Responses to $\mathrm{m}-\mathrm{MP}$ in the presence of different receptor antagonists are summarized in $(\mathrm{C})$. Bars represent mean values \pm standard error of the mean. ${ }^{* *} \mathrm{P}<0.01$ vs. control. m-PM, methanoic extract of the fruits of Prunus mume Siebold \& Zucc.; ICCs, interstitial cells of Cajal; 4-DAMP, 4-diphenylacetoxy-N-methyl-piperidine methiodide; CTRL, control; Methoct., methoctramine.

$\mathrm{Ca}^{2+}$-free condition, pacemaker potentials were abolished and were unaffected by the administration of m-PM (Fig. 4A). Pretreatment with thapsigargin $(5 \mu \mathrm{M})$ also suppressed pacemaker electrical potentials and in these conditions, m-PM had no effect on pacemaker electrical potentials (Fig. 4B). The effects of m-PM on pacemaker electrical potentials are presented in Fig. 4C $(n=6)$. These results suggest external $\mathrm{Ca}^{2+}$ or internal $\mathrm{Ca}^{2+}$ regulations modulate m-PM-induced pacemaker electrical potentials in cultured ICCs.

Association ofmitogen-activated protein kinase (MAPKs) with $m$-PM-induced pacemaker potentials of cultured ICCs. To evaluate the mechanisms involved in the interaction between $\mathrm{m}-\mathrm{PM}$ and $\mathrm{M}_{3}$ receptors, the role of mitogen-activated protein kinases (MAPKs) was investigated. It has been demonstrated that muscarinic receptors are able to activate MAPKs in various cell types $(38,39)$; therefore, the potential role of MAPKs in regulating the effects of $\mathrm{m}-\mathrm{PM}$ was determined by administrating a p42/44 MAPK inhibitor (PD98059), a p38 MAPK inhibitor (SB203580) or a c-jun NH2-terminal kinase (JNK) II inhibitor (SP600125). PD98059 (10 $\mu \mathrm{M})$, $\mathrm{m}-\mathrm{PM}$ did not induce membrane electrical depolarization (Fig. 5A). m-PM-induced membrane electrical depolarization was partially blocked by the administration of SB203580 (Fig. 5B) and completely blocked by the administration of SP600125 (Fig. 5C). The effects of m-PM on pacemaker electrical potentials are presented in Fig. 5D $(n=5)$. These results suggest that MAPKs modulate m-PM-induced pacemaker electrical potentials in cultured ICCs.

Association of TRPM7 and $\mathrm{Ca}^{2+}$-activated $\mathrm{Cl}^{-}$channels with $m$-PM-induced pacemaker potentials in cultured ICCs. In the murine small intestine, pacemaker potentials are predominantly induced by the activation of non-selective cation channels $(25,26)$ or $\mathrm{Cl}^{-}$channels $(27-29)$. To determine which channel is associated with the m-PM-induced depolarization of pacemaker potentials, the effects of m-PM on TRPM7 and

\section{A [GDP- $\beta$-S $1 \mathrm{mM}]$}

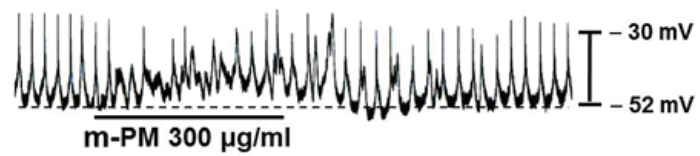

B

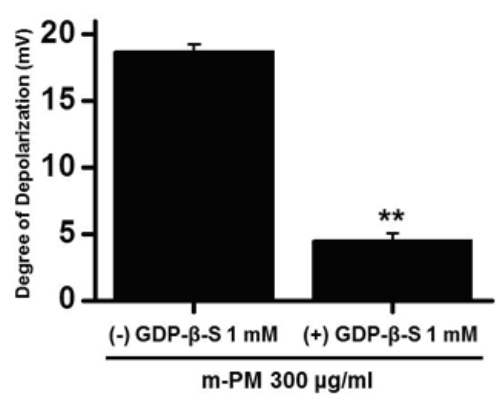

Figure 3. Effects of GDP- $\beta$-S on m-PM-induced pacemaker potential depolarization in cultured ICCs. (A) Pacemaker potentials of ICCs exposed to $\mathrm{m}-\mathrm{PM}(300 \mu \mathrm{g} / \mathrm{ml})$ in the presence of GDP- $\beta-\mathrm{S}(1 \mathrm{mM})$ in the pipette were depolarized. (B) Summary of responses to $\mathrm{m}-\mathrm{PM}$ in the presence of GDP- $\beta-\mathrm{S}$. Bars represent mean values \pm standard error of the mean. ${ }^{* *} \mathrm{P}<0.01$ vs. control. GDP- $\beta$-S, Guanosine 5'-O-(2-thiodiphosphate); m-PM, methanoic extract of the fruits of Prunus mume Siebold \& Zucc.; ICCs, interstitial cells of Cajal; CTRL, control.

$\mathrm{Ca}^{2+}$-activated $\mathrm{Cl}^{-}$channels were examined. Membranes were transfected with the FLAG-murine TRPM7/pCDNA4/TO construct using Lipofectamine 2000 (Thermo Fisher Scientific, Inc.) and $\sim 90 \%$ of cells were transfected. In a previous study, TRPM7-transfected HEK293 cells induced by tetracycline produced a flag-reactive band with a relative molecular mass of 220 kilodaltons (21). Another study revealed that ANO1 channels were overexpressed in HEK293 cells transfected with an ANO1 construct (40) and whole cell currents were recorded using patch-clamp techniques. In the present study, TRPM7 and ANO1 currents were activated in mock 


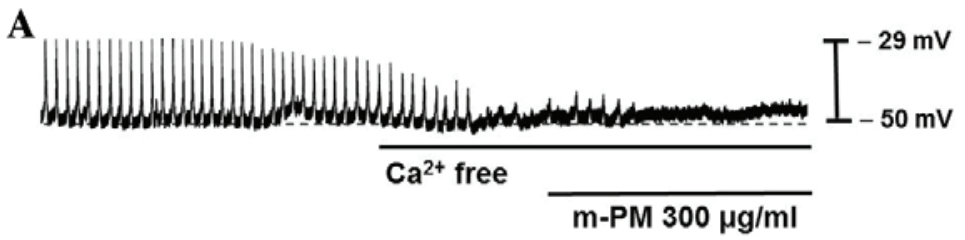

B

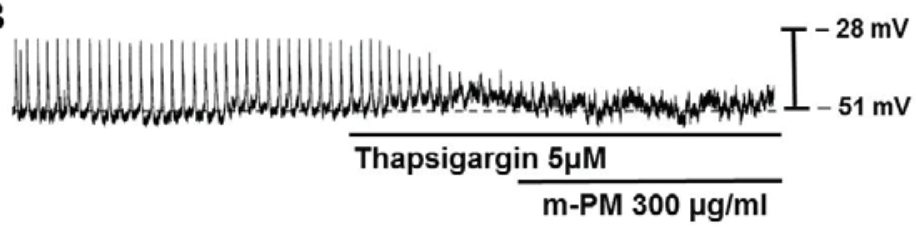

$\mathbf{C}$

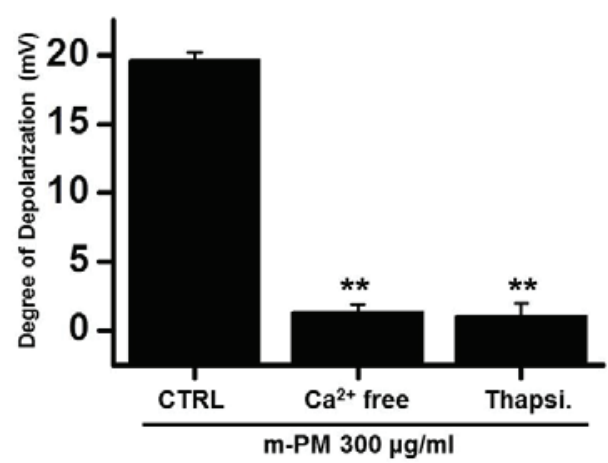

Figure 4. Effects of an external $\mathrm{Ca}^{2+}$-free solution and of thapsigargin (a $\mathrm{Ca}^{2+}$-ATPase inhibitor in endoplasmic reticulum) on m-PM-induced pacemaker potential depolarizations in cultured ICCs. (A) External $\mathrm{Ca}^{2+}$-free solution abolished the generation of pacemaker potentials and blocked m-PM-induced pacemaker depolarizations. (B) Thapsigargin $(5 \mu \mathrm{M})$ abolished pacemaker depolarizations and blocked m-PM-induced pacemaker depolarizations. (C) Responses to $\mathrm{m}-\mathrm{PM}$ in external $\mathrm{Ca}^{2+}$-free solution and in the presence of thapsigargin are summarized. Bars represent mean values \pm standard error of the mean. ${ }^{* *} \mathrm{P}<0.01$ vs. control. m-PM, methanoic extract of the fruits of Prunus mume Siebold \& Zucc.; ICCs, interstitial cells of Cajal; CTRL, control.

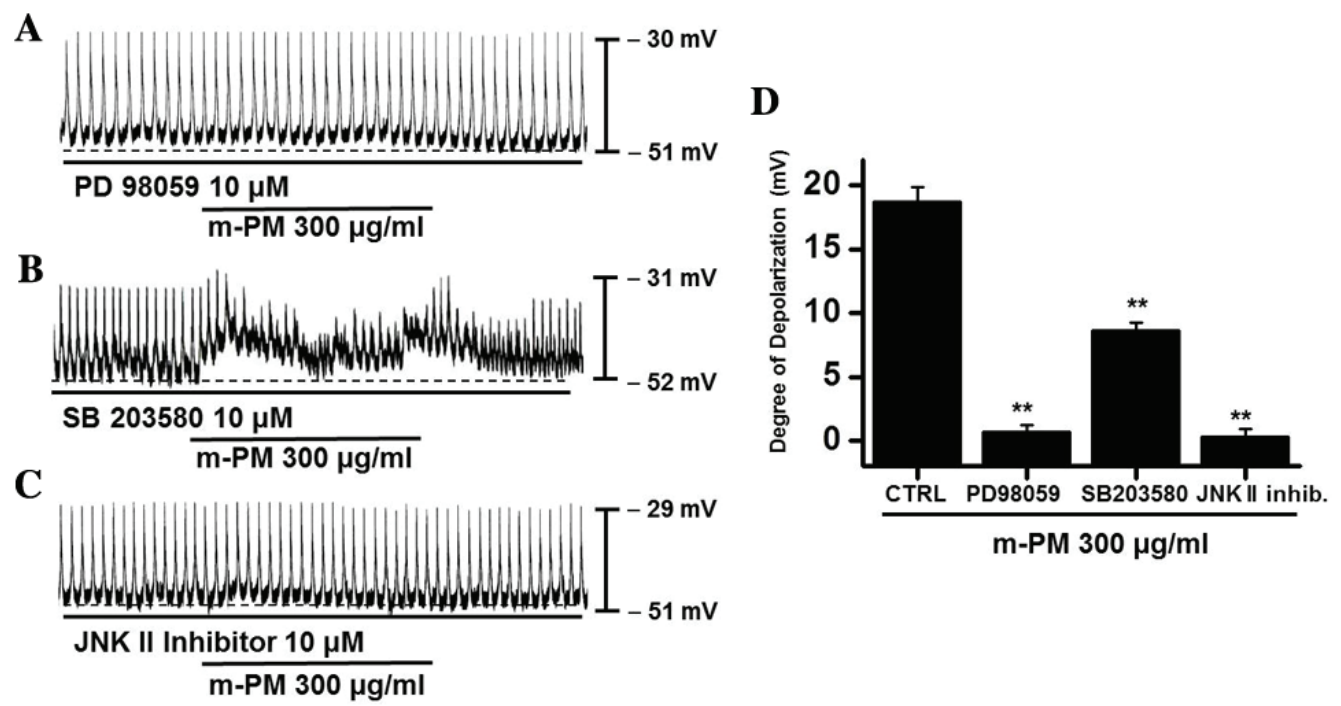

Figure 5. Effects of various MAPK inhibitors on m-PM-induced pacemaker potential responses in cultured ICCs. (A) Pacemaker potentials of cultured ICCs exposed to m-PM $(300 \mu \mathrm{g} / \mathrm{ml})$ in the presence of $10 \mu \mathrm{M}$ PD98059 (a p42/44 MAPK inhibitor). (B) Pacemaker potentials of cultured ICCs exposed to m-PM in the presence of $10 \mu \mathrm{M} \mathrm{SB} 203580$ (a p38 MAPK inhibitor). (C) Pacemaker potentials of ICCs exposed to m-PM in the presence of $10 \mu \mathrm{M}$ JNK II inhibitor. Responses to $\mathrm{m}-\mathrm{PM}$ in the presence of different MAPK inhibitors are summarized in (D). Bars represent mean values \pm standard error of the mean. ${ }^{* *} \mathrm{P}<0.01$ vs. control. MAPK, mitogen-activated protein kinase; m-PM, methanoic extract of the fruits of Prunus mume Siebold \& Zucc.; JNK II, c-jun NH2-terminal kinase; CTRL, Control.

transfected cells (Fig. 6A and B) and it was demonstrated that $\mathrm{m}$-PM inhibited the activities of TRPM7 channels, but did not affect the $\mathrm{Ca}^{2+}$-activated $\mathrm{Cl}^{-} \mathrm{ANO}$ channels (n=4; Fig. 6C-F), thus indicating that the effects of $\mathrm{m}-\mathrm{PM}$ are attributable to TRPM7 channels.

\section{Discussion}

In the present study, it was demonstrated that administration of m-PM induced depolarization of ICC pacemaker potentials through muscarinic $\mathrm{M}_{3}$ receptor signaling pathways in 
A

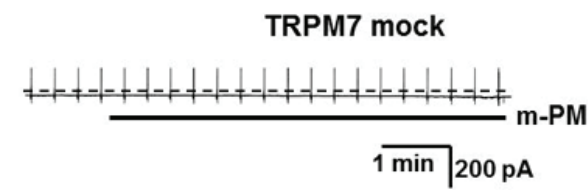

C

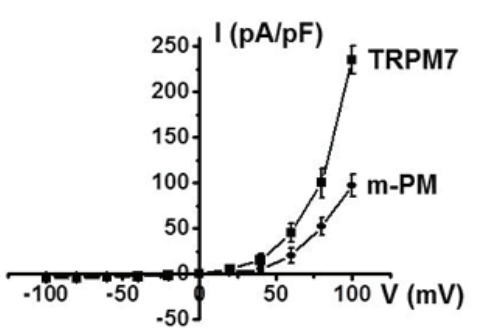

E

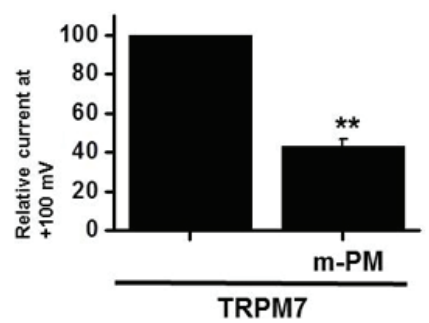

B

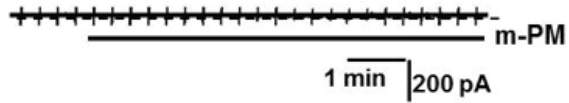

D

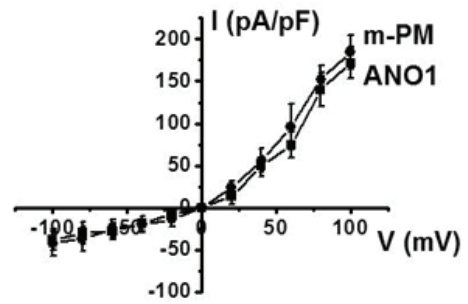

F

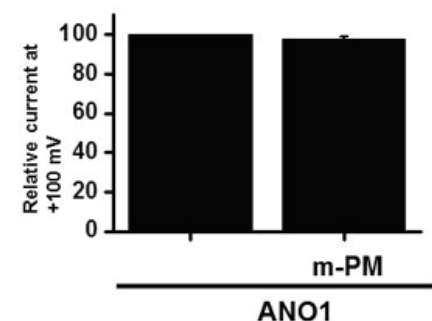

Figure 6. Effects of m-PM on overexpressed TRPM7 and ANO1 in HEK293 cells. (A) TRPM7 currents were recorded in mock transfected HEK293 cells. (B) $\mathrm{Ca}^{2+}$-activated Cl-currents were recorded in mock transfected HEK293 cells. (C) Representative I-V relationship of the effect of m-PM on TRPM7 currents in HEK293 cells. (D) Representative I-V relationship of the effect of m-PM on $\mathrm{Ca}^{2+}$-activated $\mathrm{Cl}^{-}$currents in HEK293 cells. A voltage ramp from 100 to $-100 \mathrm{mV}$ was applied from a holding potential of $-60 \mathrm{mV}$. (E and F) Summary of responses to m-PM during TRPM7 or ANO1 currents. Bars represent mean values $\pm \mathrm{SE} .{ }^{* *} \mathrm{P}<0.01 \mathrm{vs}$. TRPM7 in the absence of m-PM. m-PM, methanoic extract of the fruits of Prunus mume Siebold \& Zucc.; TRPM7, transient receptor potential melastatin type 7; ANO1, anoctamin-1, a Ca ${ }^{2+}$-activated $\mathrm{Cl}^{-}$channel; HEK 293, human embryonic kidney 293 cells; I-V, current-voltage.

a $\mathrm{G}$ protein-MAPK dependent manner. Furthermore, m-PM was able to inhibit TRPM7 currents, indicating that TRPM7 is associated with the m-PM-induced membrane depolarization of ICCs.

In intestinal motility, PM has been reported to enhance propulsive motion and small intestine motility, as determined by the coated charcoal method (7). Additionally, it has been demonstrated that PM has laxative effects in constipation rat models, as it accelerated the spontaneous contraction of isolated colon (30). Furthermore, citric and malic acid, the major organic acids in plums, stimulate spontaneous contractions in the colon (30). These findings support the commonly held belief that plums help to prevent constipation and that ICCs function as pacemakers in the small intestine thus modulating GI motility. In the present study, it was identified that m-PM depolarizes ICC pacemaker activity.

The authors of the present study have previously investigated the effects of traditional medicines on pacemaker electrical potentials in ICCs. It has been determined that Poncirus fructus (PF) is able to modulate pacemaker electrical potentials via the 5-hydroxytryptamine $(5-\mathrm{HT})_{3}$ and $5-\mathrm{HT}_{4}$ receptor pathways in a MAPK-dependent manner (24) and gintonin-mediated membrane depolarization and $\mathrm{Ca}^{2+}$-activated $\mathrm{Cl}^{-}$channel activation have been observed in cultured murine ICCs via a lysophosphatidic acid 1/3 receptor signaling pathway (41). Additionally, it was determined that San-Huang-Xie-Xin-tang (SHXXT) is able to modulate pacemaker electrical potentials (42). The results of in vivo experiments suggested that SHXXT-regulated GI motility was due to the activities of Coptidis rhizome and Rhei rhizome (42). Furthermore, Schisandra chinensis (Turcz.) Baill. extract (SC extract) was determined to modulate ICC pacemaker potentials via external and internal $\mathrm{Ca}^{2+}$ regulation, and via $\mathrm{G}$ protein and the phospholipase $\mathrm{C}$ (PLC) pathway, in a dose-dependent manner, and increased intestinal transit rates in mouse models of normal and abnormal GI motility (43). These studies indicate that traditional medicines, such as PF, ginseng, SHXXT and SC may potentially be used as gastroprokinetic agents. The results of the present study demonstrated that m-PM exhibited the potential of a prokinetic agent for GI motility dysfunctions.

The MAPK family of protein kinases serve critical roles in signal transduction $(44,45)$ and the regulation of various cellular responses, including cell cycle progression, differentiation, inflammation, protein synthesis and proliferation (46). There are five subtypes of acetylcholine muscarinic receptors $\left(M_{1}-M_{5}\right)$, of which three $\left(M_{1}, M_{3}\right.$, and $\left.M_{5}\right)$ are coupled with PLC through a $G_{q}$ protein, whereas the other subtypes $\left(M_{2}\right.$ and $\mathrm{M}_{4}$ ) are able to inhibit adenylate cyclase via $\mathrm{G}_{\mathrm{o}}$ or $\mathrm{G}_{\mathrm{i}}$ proteins (47). In various cellular systems, muscarinic receptor stimulation has been reported to activate MAPK $(48,49)$. In the present study, the effects of m-PM on ICCs in the murine small intestine were investigated. m-PM modulated pacemaker activities in ICCs through muscarinic $\mathrm{M}_{3}$ receptor activation via G protein, PLC and MAPK-dependent mechanisms. Therefore, ICCs are targets for $\mathrm{m}-\mathrm{PM}$ and this interaction may improve intestinal motility.

In conclusion, Prunus mume Siebold \& Zucc. was able to depolarize ICC pacemaker potentials in a G protein and MAPK-dependent manner by stimulating $\mathrm{M}_{3}$ receptors. 
These findings suggest that Prunus mume Siebold \& Zucc. may be developed as a potential gastroprokinetic agent for the treatment of GI motility disorders.

\section{Acknowledgements}

The present study was supported by the Research Institute for Convergence of Biomedical Science and Technology (grant no. 30-2014-011), Pusan National University Yangsan Hospital.

\section{References}

1. Jeong JT, Moon JH, Park KH and Shin CS: Isolation and characterization of a new compound from Prunus mume fruit that inhibits cancer cells. J Agric Food Chem 54: 2123-2128, 2006.

2. Kita M, Kato M, Ban Y, Honda C, Yaegaki H, Ikoma Y and Moriguchi T: Carotenoid accumulation in Japanese apricot (Prunus mume Siebold \& Zucc.): Molecular analysis of carotenogenic gene expression and ethylene regulation. J Agric Food Chem 55: 3414-3420, 2007.

3. Kim BJ, Kim JH, Kim HP and Heo MY: Biological screening of 100 plant extracts for cosmetic use (II): Anti-oxidative activity and free radical scavenging activity. Int J Cosmet Sci 19: 299-307, 1997.

4. Tsai CH, Chang RC, Chiou JF and Liu TZ: Improved superoxide-generating system suitable for the assessment of the superoxide-scavenging ability of aqueous extracts of food constituents using ultraweak chemiluminescence. J Agric Food Chem 51: 58-62, 2003.

5. Matsuda H, Morikawa T, Ishiwada T, Managi H, Kagawa M, Higashi Y and Yoshikawa M: Medicinal flowers. VIII. Radical scavenging constituents from the flowers of Prunus mume: Structure of prunose III. Chem Pharm Bull (Tokyo) 51:440-443, 2003.

6. Kim TK, Cha MR, Kim SJ, Kim SY, Jeon KI, Park HR, Park EJ and Lee SC: Antioxidative activity of methanol extract from Prunus mume byproduct. Cancer Prev Res 10: 251-256, 2005.

7. Wang L, Zhang HY and Wang L: Comparison of pharmacological effects of Fructus Mume and its processed products. Zhong Yao Cai 33: 353-356, 2010 (In Chinese).

8. Chen Y, Wong RW, Seneviratne CJ, Hägg U, McGrath C, Samaranayake LP and Kao R: The antimicrobial efficacy of Fructus mume extract on orthodontic bracket: A monospecies-biofilm model study in vitro. Arch Oral Biol 56: 16-21, 2011.

9. Seneviratne CJ, Wong RW, Hägg U, Chen Y, Herath TD, Samaranayake PL and Kao R: Prunus mume extract exhibits antimicrobial activity against pathogenic oral bacteria. Int $\mathrm{J}$ Paediatr Dent 21: 299-305, 2011.

10. Enomoto S, Yanaoka K, Utsunomiya H, Niwa T, Inada K, Deguchi H, Ueda K, Mukoubayashi C, Inoue I, Maekita T, et al: Inhibitory effects of Japanese apricot (Prunus mume Siebold et Zucc.; Ume) on Helicobacter pylori-related chronic gastritis. Eur J Clin Nutr 64: 714-719, 2010.

11. Kawahara K, Hashiguchi T, Masuda K, Saniabadi AR, Kikuchi K, Tancharoen S, Ito T, Miura N, Morimoto Y, Biswas KK, et al: Mechanism of HMGB1 release inhibition from RAW264.7 cells by oleanolic acid in Prunus mume Sieb. et Zucc. Int J Mol Med 23: 615-620, 2009.

12. Mori S, Sawada T, Okada T, Ohsawa T, Adachi M and Keiichi K New anti-proliferative agent, MK615, from Japanese apricot 'Prunus mume' induces striking autophagy in colon cancer cells in vitro. World J Gastroenterol 13: 6512-6517, 2007.

13. Kai H, Akamatsu E, Torii E, Kodama H, Yukizaki C, Sakakibara Y, Suiko M, Morishita K, Kataoka H and Matsuno K: Inhibition of proliferation by agricultural plant extracts in seven human adult T-cell leukaemia (ATL)-related cell lines. J Nat Med 65: 651-655, 2011.

14. Kim S, Park SH, Lee HN and Park T: Prunus mume extract ameliorates exercise-induced fatigue in trained rats. J Med Food 11: 460-468, 2008.

15. Youn YN, Lim E, Lee N, Kim YS, Koo MS and Choi SY: Screening of Korean medicinal plants for possible osteoclastogenesis effects in vitro. Genes Nutr 2: 375-380, 2008
16. Chuda Y, Ono H, Ohnishi-Kameyama M, Matsumoto K, Nagata T and Kikuchi Y: Mumefural, citric acid derivative improving blood fluidity from fruit-juice concentrate of Japanese apricot (Prunus mume Sieb. et Zucc). J Agric Food Chem 47: 828-831, 1999.

17. Jung BG, Cho SJ, Koh HB, Han DU and Lee BJ: Fermented Maesil (Prunus mume) with probiotics inhibits development of atopic dermatitis-like skin lesions in $\mathrm{NC} / \mathrm{Nga}$ mice. Vet Dermatol 21: 184-191, 2010.

18. Jung BG, Ko JH, Cho SJ, Koh HB, Yoon SR, Han DU and Lee BJ: Immune-enhancing effect of fermented Maesil (Prunus mume Siebold \& Zucc.) with probiotics against Bordetella bronchi septica in mice. J Vet Med Sci 72: 1195-1202, 2010.

19. Huizinga JD, Thuneberg L, Kluppel M, Malysz J, Mikkelsen HB and Bernstein A: W/kit gene required for interstitial cells of Cajal and for intestinal pacemaker activity. Nature 373: 347-349, 1995.

20. Sanders KM: A case for interstitial cells of Cajal as pacemakers and mediators of neurotransmission in the gastrointestinal tract. Gastroenterology 111: 492-515, 1996.

21. Kim BJ, Lim HH, Yang DK, Jun JY, Chang IY, Park CS, So I, Stanfield PR and Kim KW: Melastatin-type transient receptor potential channel 7 is required for intestinal pacemaking activity. Gastroenterology 129: 1504-1517, 2005.

22. Lee JH, Kim SY, Kwon YK, Kim BJ and So I: Characteristics of the cholecystokinin-induced depolarization of pacemaking activity in cultured interstitial cells of Cajal from murine small intestine. Cell Physiol Biochem 31: 542-554, 2013

23. Kim BJ, Kim SY, Lee S, Jeon JH, Matsui H, Kwon YK, Kim SJ and So I: The role of transient receptor potential channel blockers in human gastric cancer cell viability. Can J Physiol Pharmacol 90: 175-186, 2012.

24. Kim BJ, Kim HW, Lee GS, Choi S, Jun JY, So I and Kim SJ: Poncirus trifoliate fruit modulates pacemaker activity in interstitial cells of Cajal from the murine small intestine. J Ethnopharmacol 149: 668-675, 2013.

25. Koh SD, Jun JY, Kim TW and Sanders KM: A Ca ${ }^{2+}$-inhibited non-selective cation conductance contributes to pacemaker currents in mouse interstitial cell of Cajal. J Physiol 540: 803-814, 2002.

26. Kim BJ, So I and Kim KW: The relationship of TRP channels to the pacemaker activity of interstitial cells of Cajal in the gastrointestinal tract. J Smooth Muscle Res 42: 1-7, 2006.

27. Huizinga JD, Zhu Y, Ye J and Molleman A: High-conductance chloride channels generate pacemaker currents in interstitial cells of Cajal. Gastroenterology 123: 1627-1636, 2002.

28. Hwang SJ, Blair PJ, Britton FC, O'Driscoll KE, Hennig G, Bayguinov YR, Rock JR, Harfe BD, Sanders KM and Ward SM: Expression of anoctamin 1/TMEM16A by interstitial cells of Cajal is fundamental for slow wave activity in gastrointestinal muscles. J Physiol 587: 4887-4904, 2009.

29. Zhu MH, Kim TW, Ro S, Yan W, Ward SM, Koh SD and Sanders KM: A Ca ${ }^{2+}$-activated $\mathrm{Cl}(-)$ conductance in interstitial cells of Cajal linked to slow wave currents and pacemaker activity. J Physiol 587: 4905-4918, 2009.

30. Na JR, Oh KN, Park SU, Bae D, Choi EJ, Jung MA, Choi CY, Lee DW, Jun W, Lee KY, et al: The laxative effects of Maesil (Prunus mume Siebold \& Zucc.) on constipation induced by a low-fibre diet in a rat model. Int J Food Sci Nutr 64: 333-345, 2013.

31. National Research Council: Guide for the Care and Use of Laboratory Animals. National Academies Press (US), Washington (DC), 2011

32. Huizinga JD, Chang G and Diamant NE, El-Sharkawy TY: Electrophysiological basis of excitation of canine colonic circular muscle by cholinergic agents and substance P. J Pharmacol Exp Ther. 231: 692-699, 1984.

33. Inoue R and Chen S: Physiology of muscarinic receptor operated nonselective cation channels in guinea-pig ilieal smooth muscle. EXS 66: 261-268, 1993.

34. Epperson A, Hatton WJ, Callaghan B, Doherty P, Walker RL, Sanders KM, Ward SM and Horowitz B: Molecular markers expressed in cultured and freshly isolated interstitial cells of Cajal. Am J Physiol Cell Physiol 279: C529-C539, 2000.

35. Komori S, Kawai M, Takewaki T and Ohashi H: GTP-binding protein involvement in membrane currents evoked by carbachol and histamine in guinea-pig ileal muscle. J Physiol 450: 105-126, 1992.

36. Ogata $\mathrm{R}$, Inoue $\mathrm{Y}$, Nakano $\mathrm{H}$, Ito $\mathrm{Y}$ and Kitamura $\mathrm{K}$ : Oestradiol-induced relaxation of rabbit basilar artery by inhibition of voltage-dependent Ca channels through GTP-binding protein. Br J Pharmacol 117: 351-359, 1996. 
37. Ward SM, Ordog T, Koh SD, Baker SA, Jun JY, Amberg G Monaghan K and Sanders KM: Pacemaking in interstitial cells of Cajal depends upon calcium handling by endoplasmic reticulum and mitochondria. J Physiol 525: Pt 2 355-361, 2000.

38. Yagle K, Lu H, Guizzetti M, Möller T and Costa LG: Activation of mitogen-activated protein kinase by muscarinic receptors in astroglial cells: Role in DNA synthesis and effect of ethanol. Glia 35: 111-120, 2001.

39. Sakai H, Otogoto S, Chiba Y, Abe K and Misawa M: Involvement of $\mathrm{p} 42 / 44$ MAPK and RhoA protein in augmentation of ACh-induced bronchial smooth muscle contraction by TNF-alpha in rats. J Appl Physiol (1985) 97: 2154-2159, 2004.

40. Nam JH, Kim WK and Kim BJ: Sphingosine and FTY720 modulate pacemaking activity in interstitial cells of Cajal from mouse small intestine. Mol Cells 36: 235-244, 2013.

41. Kim BJ, Nam JH, Kim KH, Joo M, Ha TS, Weon KY, Choi S, Jun JY, Park EJ and Wie J: Characteristics of gintonin-mediated membrane depolarization of pacemaker activity in cultured interstitial cells of Cajal. Cell Physiol Biochem 34: 873-890, 2014.

42. Kim BJ, Kim H, Lee GS, So I and Kim SJ: Effects of San-Huang-Xie-Xin-tang, a traditional Chinese prescription for clearing away heat and toxin, on the pacemaker activities of interstitial cells of Cajal from the murine small intestine. J Ethnopharmacol 155: 744-752, 2014.
43. Ahn TS, Kim DG, Hong NR, Park HS, Kim H, Ha KT, Jeon JH, So I and Kim BJ: Effects of Schisandra chinensis extract on gastrointestinal motility in mice. J Ethnopharmacol 169: 163-169, 2015.

44. Garrington TP and Johnson GL: Organization and regulation of mitogen-activated protein kinase signaling pathways. Curr Opin Cell Biol 11: 211-218, 1999.

45. Derkinderen P, Enslen H and Girault JA: The ERK/MAP-kinases cascade in the nervous system. Neuroreport 10: R24-R34, 1999.

46. Lukacs NW, Strieter RM, Chensue SW, Widmer M and Kunkel SL: TNF-alpha mediates recruitment of neutrophils and eosinophils during airway inflammation. J Immunol 154: 5411-5417, 1995.

47. Nathanson NM: A multiplicity of muscarinic mechanisms: Enough signaling pathways to take your breath away. Proc Natl Acad Sci USA 97: 6245-6247, 2000.

48. Slack BE: The M3 muscarinic acetylcholine receptor is coupled to mitogen-activated protein kinase via protein kinase $\mathrm{C}$ and epidermal growth factor receptor kinase. Biochem J 348: Pt 2 381-387, 2000.

49. Yagle K, Lu H, Guizzetti M, Möller T and Costa LG: Activation of mitogen-activated protein kinase by muscarinic receptors in astroglial cells: Role in DNA synthesis and effect of ethanol. Glia 35: 111-120, 2001. 